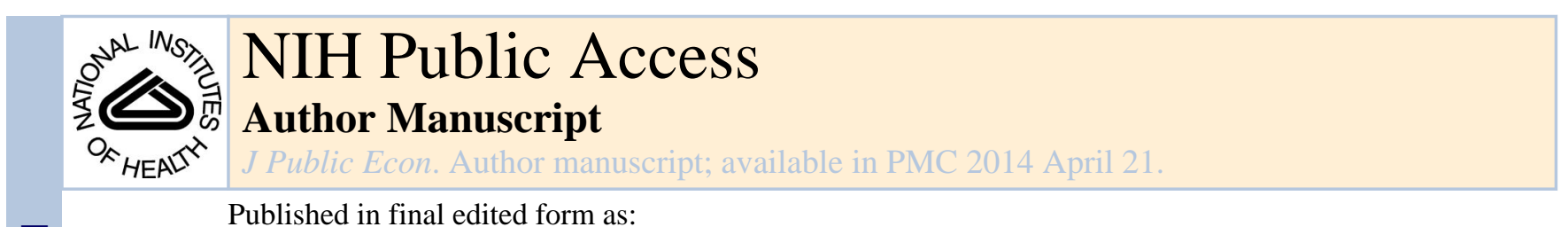

Published in final edited form as:

J Public Econ. 2008 August ; 92(8-9): 1787-1794. doi:10.1016/j.jpubeco.2008.04.010.

\title{
How Are Preferences Revealed?
}

\author{
John Beshears \\ Harvard University \\ James J. Choi \\ Yale University and NBER \\ David Laibson \\ Harvard University and NBER \\ Brigitte C. Madrian \\ Harvard University and NBER
}

\section{Abstract}

Revealed preferences are tastes that rationalize an economic agent's observed actions. Normative preferences represent the agent's actual interests. It sometimes makes sense to assume that revealed preferences are identical to normative preferences. But there are many cases where this assumption is violated. We identify five factors that increase the likelihood of a disparity between revealed preferences and normative preferences: passive choice, complexity, limited personal experience, third-party marketing, and intertemporal choice. We then discuss six approaches that jointly contribute to the identification of normative preferences: structural estimation, active decisions, asymptotic choice, aggregated revealed preferences, reported preferences, and informed preferences. Each of these approaches uses consumer behavior to infer some property of normative preferences without equating revealed and normative preferences. We illustrate these issues with evidence from savings and investment outcomes.

Revealed preference theory constructs utility functions that rationalize empirical observations of consumer choices and consumer budget constraints (Samuelson, 1938, 1948; Little, 1949; Houthakker, 1950; Afriat, 1967). Economists usually assume that these revealed preferences are also normative preferences—-preferences that represent the economic actor's true interests. Economic welfare analysis and policy analysis almost always assume that revealed preferences and normative preferences are identical.

\section{(C) 2008 Elsevier B.V. All rights reserved.}

John Beshears Department of Economics Harvard University Littauer Center Cambridge, MA 02138 beshears@fas.harvard.edu. James J. Choi Yale School of Management 135 Prospect Street P.O. Box 208200 New Haven, CT 06520-8200 james.choi@yale.edu. David Laibson Department of Economics Harvard University Littauer Center Cambridge, MA 02138 dlaibson@ harvard.edu. Brigitte C. Madrian School of Government Harvard University 79 JFK Street Cambridge, MA 02138 Brigitte_Madrian@harvard.edu.

Publisher's Disclaimer: This is a PDF file of an unedited manuscript that has been accepted for publication. As a service to our customers we are providing this early version of the manuscript. The manuscript will undergo copyediting, typesetting, and review of the resulting proof before it is published in its final citable form. Please note that during the production process errors may be discovered which could affect the content, and all legal disclaimers that apply to the journal pertain.

Prepared for the "Happiness and Public Economics Conference" held at the London School of Economics in September 2006. 
In some situations, it makes sense to give revealed preferences normative status. When a ten-year-old child chooses chocolate over vanilla ice cream, she reveals a legitimate preference for one flavor over another. The government should respect that preference, and ice cream parlors should cater to it.

However, there are many cases in which even the choices of adult consumers do not reveal a true preference, but rather reflect the combined influence of true preferences and decisionmaking errors. When a worker invests all of her retirement savings in her employer's stock, economists should not necessarily assume that she has acted in her best interest. In surveys, workers on average report that an investment in their employer's stock is less risky than an investment in a diversified mutual fund (John Hancock Financial Services, 2002). When workers put all their financial eggs in one basket, they are probably revealing many things, one of which is confusion about the true risk characteristics of their employer's stock.

Human behavior is jointly determined by both normative preferences and other factors such as analytic errors, myopic impulses, inattention, passivity, and misinformation. Despite these complications, economists need not throw up their hands and reject all revealed preferences. This paper describes a compromise that uses behavior to identify normative preferences while acknowledging that revealed preferences often differ from normative preferences. We summarize and extend a long line of economic research that proposes empirical and policy frameworks that distinguish between revealed and normative preferences (e.g. Luce, 1959; Laibson, Repetto, and Tobacman, 1998; Camerer et al., 2003; Bernheim and Rangel, 2007; Thaler and Sunstein, 2008).

In Section 1, we describe the kinds of situations where normative preferences are least likely to be revealed by people's choices. We illustrate these issues with evidence from savings and investment decisions. We identify five factors that increase the likelihood that revealed preferences will not have normative merit: passive choice, complexity, limited personal experience, third-party marketing, and intertemporal choice.

Section 2 discusses six frameworks that can jointly contribute to the identification of normative preferences: structural estimation, active decisions, asymptotic choice, aggregated revealed preferences, reported preferences, and informed preferences. Each framework relies on consumer behavior to infer some property of normative preferences without equating revealed and normative preferences.

Practical policy analysis should use insights from all the six frameworks discussed in Section 2. Section 3 concludes with a discussion of how to design institutions-including government policies-when there is likely to be a gap between revealed and normative preferences.

\section{Red flags}

In this section we discuss five factors-passive choice, complexity, limited personal experience, third-party marketing, and intertemporal choice - that often create a wedge between revealed and normative preferences. 


\subsection{Passive choice}

In many situations, economic agents do not actively make choices. Instead, they passively accept defaults that are chosen by others. In theory, acceptance of a default could be a conscious and meaningful decision. In practice, acceptance of a default often reflects other forces, like procrastination.

For instance, an agent may accept a default she knows is not optimal because she plans to switch to a superior alternative soon. However, if the agent procrastinates, this switch will not materialize or will be delayed. Such procrastination dynamics are especially likely to arise when the marginal cost of delaying an additional day is small, leading to long total delays and significant cumulative costs. (See Akerlof, 1991, for a theoretical example and Madrian and Shea, 2001, and Choi, Laibson and Madrian, 2005b, for empirical examples.)

Highly suggestible agents may also accept defaults because they believe-perhaps erroneously - that the person who set the default was making a carefully considered recommendation (Madrian and Shea, 2001; Beshears et al., 2006a).

Preferences revealed through passive choice are often inconsistent, since variation in defaults generates large variation in (passively) accepted outcomes. ${ }^{1}$ For example, Choi, Laibson, Madrian, and Metrick (2006) examine four companies that changed the default enrollment regime for their retirement savings plans. When the default is non-participation (an opt-in default), enrollment rates range from 25\% to $43 \%$ six months after hire (despite the existence of a large employer match at three of the four firms). By comparison, when the default is automatic enrollment (with an option to opt out), enrollment rates range from $86 \%$ to $96 \%$ six months after hire. At these four firms, automatic enrollment increases participation by 50 to 67 percentage points.

The impact of defaults on savings outcomes extends well beyond savings plan participation. Similar effects have been documented for almost every aspect of retirement saving, including asset allocation, contribution rates, pre-retirement cash distributions, and annuitization (see Beshears et al., 2006a, for a summary of this research).

\subsection{Complexity}

Problems that are hard to solve tend to delay choice because they force agents to incur large up-front problem-solving costs. Thus, complexity increases the fraction of individuals that accept default options (O'Donoghue and Rabin, 1999a). Complexity also biases choice, since people tend to avoid more complicated alternatives (Shafir et al., 1993; Iyengar and Kamenica, 2006). Finally, complexity adds noise to choices. Since complicated options may not be well-understood, some consumers choosing a complicated option will do so because they misestimate its value (Luce, 1959; McFadden, 1981; Gabaix, Laibson, and Li, 2005).

\footnotetext{
${ }^{1}$ See, for example, Madrian and Shea (2001), Choi, Laibson, Madrian, and Metrick (2002, 2004, 2006), Johnson and Goldstein (2003), Abadie and Gay (2006), Listokin (2006), Johnson et al. (1993), Aura (2001), Park et al. (2000), Cronqvist and Thaler (2004), and Holden and Nicholson (1998)
} 
1.2.1. Complexity and the number of choices-The large number of available investment options makes asset allocation decisions complex. For instance, at year-end 2005, there were 8,454 mutual funds registered in the United States. ${ }^{2}, 3$ Allocating money across these mutual funds is an overwhelming task unless the agent employs a heuristic, such as considering the mutual funds at only one asset management company.

Iyengar and Kamenica (2006) show that experimental subjects are more likely to choose a simple (risk-free) investment than a complex (risky) investment as the number of investment options increases. Iyengar and Kamenica also find support for this result in a cross-section of 401(k) plans: for every 10 additional mutual funds in a 401(k) investment menu, the average allocation to equities is 3.3 percentage points lower.

A superabundance of options also delays savings plan enrollment. A typical employersponsored savings plan allows employees select any contribution rate up to 15 or 20 percent of their pay (subject to IRS contribution limits), and balances can be invested in any convex combination of - on average-14 different investment options (U.S. Bureau of Labor Statistics, 2005; Hewitt Associates, 2005). Iyengar, Huberman and Jiang (2004) document a negative relationship between the number of investment options offered in a savings plan and employee participation: each additional 10 funds in the menu of investment options is associated with a decline in participation rates of 1.5 to 2.0 percentage points. Conversely, Choi, Laibson, and Madrian (2006a) and Beshears et al. (2006b) show that simplifying the savings plan enrollment decision increases participation rates. They study an intervention at two firms in which non-participating employees were given the opportunity to opt into a single pre-selected contribution rate and asset allocation. Even though the number of 401(k) choices available did not decrease, this simplified reframing of the enrollment decision increased participation by 10 to 22 percentage points.

1.2.2. Complexity and long horizons-Choices with distant consequences are more complex. Forecasting what will happen later today is much easier than forecasting events on a particular afternoon four decades from now. Looking ahead forty years, one needs to consider numerous divergent paths: unemployment, sickness, divorce, bankruptcy, bequests, etc.

Decisions with consequences in the distant future reflect both normative preferences and forecasting errors. Some of those forecasting errors will be predictable. For example, recently released estimates from the Centers for Medicare and Medicaid Services project a $7.2 \%$ annual increase in health care spending for the years 2005-2015, outstripping both the annual rates of GDP growth and overall inflation (Borger et al., 2006). It is likely that many households are not aware of these forecasts. The inferences that economists draw regarding households' intertemporal preferences depend critically on whether households foresee these health costs (some of which they will need to bear). If we observe a low current savings rate, that could reflect either a high discount rate and a rational forecast of future health costs or a

\footnotetext{
2 Investment Company Institute, 2006 Investment Company Fact Book. See www.icifactbook.org.

${ }^{3}$ There are also many thousands of other investment vehicles, including ETFs, hedge funds, and derivatives.
} 
low discount rate and an under-estimate of future health costs. It is hard for the social scientist to know which mechanism is at play.

\subsection{Limited personal experience}

Limited personal experience creates another wedge between revealed preferences and normative preferences. Human learning is often generated by feedback. A child learns that hot food burns the roof of his mouth through experience rather than lectures. Likewise, video renters learn to return their videos on time after paying a late fee (Fishman and Pope, 2007), and credit card account holders learn to pay their bills on time by first paying late fees (Agarwal et al., 2007).

Consumers with little or no feedback are not likely to learn what is in their best interest. What personal experiences could teach a middle-aged worker whether she is saving the right amount for retirement? In principle, she could learn by observing others, particularly people in older generations. However, every generation faces different financial circumstances, so the applicability of prior generations' experience is unclear. Moreover, people are generally far more responsive to their own experiences than the experiences of others. For example, Choi, Laibson, and Madrian (2005a) show that when Enron, WorldCom, and Global Crossing employees' 401(k) balances-which were heavily invested in their employer's stock-were wiped out by those companies' bankruptcies, workers at other U.S. firms did little to reduce their own investments in employer stock.

\subsection{Third-party marketing}

Tom Sawyer tricked his friends into paying him for the privilege of painting his family's fence. A great deal of real behavior is also influenced by marketing. For example, S\&P 500 index funds charge fees that vary by an order of magnitude (Hortaçsu and Syverson, 2004). Moreover, this range of fees cannot be explained by variation in bundled non-portfolio services, such as customer service quality (Choi, Laibson, and Madrian, 2006b). Instead, the willingness to pay high fees is partially due to the effective marketing and branding of the underlying good — an index fund—which is a commodity.

It is not obvious how economists should evaluate preferences for branded commodities (cf. Becker and Murphy, 1993). If people feel good when they drink Coke out of a Coke bottle, ${ }^{4}$ it might not be problematic that they buy Coke even though they prefer the taste of Pepsi in double-blind tastes (McClure et al., 2004). However, there are some cases where such brand preferences may not deserve normative weight. When asset management firms induce their clients to invest in dominated (high-fee) assets and when employers persuade their rank-andfile workers to hold employer stock, economists should wonder whether these revealed preferences have normative legitimacy or reflect mistakes (cf. Ariely et al., 2003).

\subsection{Intertemporal choice}

Intertemporal choices raise two sets of normative questions. First, even if an economic agent makes choices that imply a consistent discount rate, it is not obvious that that revealed

\footnotetext{
${ }^{4}$ Advertising has endowed Coke with many positive affective associations: family, friends, small-town America, etc.
} 
discount rate should be accorded normative status (Ramsey, 1928; Pigou, 1932; Harrod, 1948; Solow, 1974; Kahneman et al., 1997; Anand and Sen, 2000). Why should utility experienced at date $t$ have less weight than utility experienced at a later date $t+\tau$ ? Only discounting due to mortality risk is easily defended philosophically (see previous citations). However, mortality discounting is an order of magnitude too small to explain the intertemporal preferences revealed by actual households' savings choices; ${ }^{5}$ the revealed exponential discount rate is around 5\% per year (e.g., Gourinchas and Parker, 2002).

Recently Nordhaus (2006) has shown that the policy recommendations for addressing global warming hinge critically on the normative discount rate. For example, the highly influential Stern report (2006) bases its benchmark analysis on a normative discount rate of $0.1 \%$ per year, which is $1 / 50^{\text {th }}$ the magnitude of the revealed preference discount rate of $5 \%{ }^{6}$

The discussion in the previous two paragraphs posits the existence of a constant revealed discount rate, and then asks whether the normative discount rate should match it. However, a growing body of evidence suggests that revealed discount rates are not constant. Instead, discount rates are higher in the short run than the long run (Ainslie, 1992; Loewenstein and Prelec, 1992; Laibson, 1997; Angeletos et al., 2001; DellaVigna and Malmendier, 2006). Such variation raises a host of additional normative problems. One particularly salient problem is that non-constant discount rates imply dynamically inconsistent preferences.

To illustrate this problem, imagine that a person can make an investment at a cost of $C$ utils to gain delayed benefits of $B$ utils. For analytic simplicity, assume that benefits occur one period after the costly investment. The individual has a quasi-hyperbolic discounting function (Phelps and Pollak, 1968; Laibson, 1997), whereby rewards and costs at times 0, 1, $2,3, \ldots$, are multiplied by respective weights $1, \beta \cdot \delta, \beta \cdot \delta^{2}, \beta \cdot \delta^{3}, \ldots$, with $0<\beta \leq 1$ and $0<\delta$ $\leq 1$. When $\beta=1$, this model is identical to the classical exponential discounting model. When $\beta<1$, this model reproduces the "hyperbolic" pattern of more discounting in the short run and less discounting in the long run. O'Donoghue and Rabin (1999b) call these preferences "present-biased."

Consider the case in which $\beta=1 / 2$ and $\delta=1$ (the value $\delta=1$ is used in Akerlof, 1991). Set $C=4$ and $B=6$, so the undiscounted cost of investment is 4 and the undiscounted benefit is 6. With these parameter values, the investment looks appealing when viewed from a temporal distance:

$$
-\beta \delta^{t} C+\beta \delta^{t+1} B=-(1 / 2)(4)+(1 / 2)(6)=1>0 .
$$

However, the investment is undesirable if the agent is asked to do it right now:

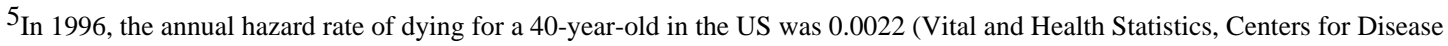
Control and Prevention/National Center for Health Statistics, 1999).

6 From the FAQ section of the Stern report: "We carefully examine the case for discounting the future just because it is the futurewhich in economic terms is known as pure time preference. This requires a consideration of the ethical issues involved in comparing the incidence of costs and benefits between generations, some of which are distant in time. We argue-in line with economists including Ramsey, Sen, Pigou and Solow - that the welfare of future generations should be treated on a par with our own. This means that the only justification for a positive rate of pure time preference in assessing the impacts of climate change is the possibility that the human race may be extinguished. As the possibility of this happening is low, we assume a low rate of pure time preference, $0.1 \%$."
} 


$$
-C+\beta \delta B=-(4)+(1 / 2)(6)=-1<0 .
$$

Hence, a person with this discounting function has two competing sets of revealed preferences. When asked to make decisions in advance, the agent will choose to invest. When such decisions are not binding, the agent will not end up investing (since she always breaks her previous plans when the moment of action arises). In situations like this, revealed preferences cannot be a reliable guide to normative preferences. Alternative or additional normative assumptions are needed (cf. Bernheim and Rangel, 2007).

\section{Inferring normative preferences}

The previous section described situations in which revealed preferences deviate from normative preferences. For policy purposes, economists would like to identify normative preferences when such deviations occur. In the current section, we summarize six methods for doing so. None of these methods is ideal, and all of them should be viewed as complementary ways of measuring normative preferences. As we discuss each method, we will review its strengths and weaknesses.

\subsection{Structural estimation}

For an economist trained in modern empirical methods, a natural way to measure normative preferences is to estimate them with a structural model. Such a model would have two components:

1. A (positive) behavioral model with a parameter vector $\theta$

2. A set of normative axioms that map the parameters $\theta$ into normative preferences

The behavioral model would incorporate all of the economic and psychological motives that shape behavior, including the mechanisms that generate mistakes (e.g., non-Bayesian inference) and the preferences that are normatively illegitimate (e.g., present bias ${ }^{7}$ ).

To implement this analysis, experimental data or field data would be used to estimate the parameter vector $\boldsymbol{\theta}$ in behavioral model (1). These parameters would then be mapped into normative preferences using the axioms in (2).

As an example, suppose consumers' static revealed preferences are normatively legitimate but their dynamic preferences are not, as in the case where they suffer from present bias. Such an argument would be supported by the normative axiom that the welfare function should have no intertemporal discounting except for that due to mortality risk (Ramsey, 1928; Pigou, 1932; Harrod, 1948; Solow, 1974; Kahneman et al., 1997; Anand and Sen, 2000). At the same time, the normative axioms might respect people's static preferences over risky alternatives. In this example, $\theta$ would contain both static risk aversion parameters and dynamic discounting parameters. Both types of parameters would be simultaneously

${ }^{7}$ Laibson (1997), O’Donoghue and Rabin (1999b). 
estimated from available data, ${ }^{8}$ but only the static risk preferences would be elevated to normative status.

This structural estimation framework has the strength that it forces the researcher to make clear assumptions about behavioral biases while enabling the researcher to simultaneously identify both normative preferences and the underlying behavioral model. On the other hand, the structural model has the weakness that it is costly to implement-like most structural models - and it may not be robust to model specification errors.

\subsection{Active decisions}

In some cases, revealed preferences and normative preferences diverge because people stay at a default that even they report is not in their best interest. For example, two-thirds of survey respondents at one company reported that their current savings rate was too low relative to their ideal savings rate. A third of these undersavers said they were planning to increase their savings plan contribution rate in the next two months, but almost none of them actually did so (Choi, Laibson, Madrian, and Metrick, 2002 and 2006). (We will discuss self-reported preferences further in Section 2.5.)

In situations like this, outcomes vary with the type of default that is used. As discussed in Section 1.1, savings plan participation rates vary enormously with the participation default that is chosen: opt-in versus opt-out. The default biases outcomes, both because consumers tend to procrastinate and because consumers tend to follow the implicit advice that a default represents. To the extent that the wedge between normative and revealed preferences is created by inertia around the default, a default-free mechanism may produce outcomes closer to the normative benchmark. For example, an active decision mechanism forces individuals to explicitly state their preferences (Carroll et al., 2007). Active decision mechanisms have no default option. ${ }^{9}$

In the context of an employer-sponsored savings plan, such an approach might require all workers to affirmatively state whether they do or do not want to participate in the savings plan. Workers would be required to announce this preference by a certain deadline. Carroll et al. (2007) document that the enrollment rate achieved under an active decision regime lies between the rate obtained under an opt-in system (default is non-enrollment) and the rate obtained under an opt-out system (default is enrollment). Active decision participation rates are slightly closer to the participation rates achieved under the latter regime.

\subsection{Asymptotic choice}

In most stationary economic environments, short-run choices are likely to be further from normative optimality than long-run choices (Plott, 1996). ${ }^{10}$ For example, in firms with saving plans that use a non-enrollment (opt-in) default, procrastination may delay

\footnotetext{
${ }^{8}$ See Laibson, Repetto, and Tobacman (2006) for an example of such a structural estimation without any normative interpretation. ${ }^{9}$ In practice, there is a default, but the default is only used in the case when the agent refuses to make a decision for herself. For example, in an active decision implementation (Carroll et al., 2007), employees at a firm were told that they had to make an active savings plan participation decision within 30 days of their hire date. Approximately $95 \%$ did so, though some employees needed repeated reminders to nudge them into compliance. The 5\% of employees who ignored these reminders were eventually given the (hidden) default of non-enrollment. One could raise the compliance rate by punishing non-compliance, but such punishments might be socially inefficient.
} 
enrollment, thereby biasing downward the short-run participation rate. Learning mechanisms —including imitation of peers, educational seminars, and experiential feedback—may also make long-run choices better than short-run choices.

Hence, it is likely that the participation/savings behavior of experienced workers is normatively more informative than the behavior of inexperienced workers. One should therefore give disproportionate weight to the investment behavior of high-tenure workers when attempting to infer normative preferences (Choi, Laibson, Madrian, and Metrick, 2003; Carroll et al., 2007).

Credit card data provide strong evidence of learning effects. Controlling for person fixed effects and transitory account characteristics, new account holders pay fees that are four times greater than the fees paid by experienced account holders (Agarwal et al., 2007). ${ }^{11}$ The fees paid by new account holders reflect mistakes that are avoided by more experienced account holders. Each time an account holder pays a fee-for instance, a late payment feeher likelihood of paying that fee the next month drops by a third.

When new account holders pay fees, most of them are not revealing a high willingness to pay fees in exchange for services (like paying $\$ 30$ for the service of being able to pay one's bill late). Instead, most new account holders are revealing that they have not yet optimized their account management skills. With time and experience, such optimization takes place, and fee payments dramatically decline. It is this decline-learning - that differentiates mistakes from price discrimination. It is therefore the asymptotic behavior that reflects the normative preferences of the account holders.

\subsection{Aggregated revealed preferences}

In some settings, agents make noisy, error-prone decisions. Despite these errors, aggregate behavior contains some useful normative information. For example, consider the case in which agent's choices are equal to optimal behavior plus noise with a mean that is close to zero. Then aggregate behavior reveals information about the central tendencies of normative preferences. Nevertheless, aggregate behavior masks critical information about heterogeneity in normative preferences. It would be inappropriate to mandate that people choose the average behavior of their unconstrained peers.

However, averages can nevertheless be useful normative tools. For instance, individual agents may make better decisions if they are informed about the aggregate choices of their peers. Aggregate revealed preferences may also serve as useful defaults.

In some cases decision errors will not have a mean near zero. In such situations inferences from a population's central moments can lead to biased conclusions. The common phenomenon of employer stock holding in employer sponsored retirement savings plans is likely to be a manifestation of a non-zero-mean error. ${ }^{12}$

\footnotetext{
10Plott (1996) describes the "discovered preferences hypothesis." The quality of decisions evolves with experience. In stage 1, choices are noisy and prone to reflect errors. In stage 2, choices become systematic but still do not reflect a complete strategic understanding of the environment. In stage 3 , choices become stable and strategically rational.

${ }^{11}$ For this analysis, experienced account holders have at least four years of feedback.
} 


\subsection{Self-reported preferences}

In many cases, decision-makers report that they know what they should do but nevertheless fail to implement that action. For example, $70 \%$ of smokers in the U.S. report that they want to quit. Moreover, $41 \%$ temporarily stopped smoking for a day or more during the previous twelve months in an unsuccessful attempt to quit (Centers for Disease Control and Prevention, 2002). At the company discussed in Section 2.2, many workers said they planned on saving more soon, but almost none of them actually did so. The preference workers revealed through their actions contradicts their reported preference.

Historically, economists have rejected self-reports on the grounds that behavior has real consequences and self-reports are (usually) only cheap talk. We agree that self-reports can't be taken at face value, but we also believe that they should not be ignored completely. In our view, successful models of human decision-making should be able to explain both behavior and self-reports. Like behavior, self-reports can be measured and modeled. ${ }^{13}$ Like behavior, self-reports can be used to predict things that economists unambiguously care about (like future behavior).

We recognize that self-reports are sometimes motivated by signaling, but behavior can also be driven by signaling motives. Self-reports often reveal at least something about an agent's goals and values. Normative economics should allow self-reports to have some standing. It would be strange to try to infer someone's normative preferences without at least considering their own stated views on the question.

Finally, self-reports can be used to assess a consumer's confidence that his behavioral choices are optimal. Choi, Laibson, and Madrian (2006b) find that consumers who choose low-fee index funds are more confident about their investment choice than consumers who choose high-fee index funds. Hence, self-reports may provide a natural tool for discovering when revealed preferences diverge most from normative preferences. In this view, economists should be more willing to interpret revealed preferences as normative preferences when consumers report that they are confident in their own choices.

Finally, reported preferences have different contextual features than revealed preferences. For example, four hours before a diner goes to a restaurant, you can ask her how many courses she plans to eat. But it is difficult for the economist to measure the time $t-4$ preference with behavior. ${ }^{14}$ In this sense, reported preferences offer a far richer range of contexts than revealed preferences. The measurement of revealed preference is essentially limited to the diner's choices at the restaurant. The diner's reported preferences can be measured at any time and in any context (e.g. when she is trying on a wedding dress or when she is inspecting the dessert tray at a Michelin 3-star restaurant).

\footnotetext{
${ }^{12}$ Alternatively, significant holdings of employer stock could be modeled with zero mean decision errors (with a high variance) and a behavioral constraint that prevents agents from shorting company stock.

${ }^{13}$ For example, models of naïve quasi-hyperbolic agents (Akerlof, 1991; O’Donoghue and Rabin, 1999a, 1999b) predict a gap between self-reported plans and actual subsequent behavior.

${ }^{14}$ There is, however, a new business that encourages people to write financially binding commitment contracts that would reveal such in-advance preferences: http://stickk.com/
} 


\subsection{Informed preferences}

Informed opinions come in two forms. First, external observers may offer expert advice (e.g., academics, consultants, financial planners, etc.). Second, decision-makers may themselves gain more expertise when they receive formal training and education. When trained/educated decision-makers make a choice, we call this an "informed preference."

In our view, both sources of expert opinion-external experts and educated consumersshould play a role in the identification of normative preferences. This is particularly true when exogenous education or training can be shown to systematically change people's behavior. Naturally, there are limits to such arguments, especially when "education" is little more than marketing or brainwashing. However, at least some education is not overwhelmed by these problems. When economists measure normative preferences, we should give disproportionate weight to the actors who have substantial domain-relevant human capital and do not suffer from conflicts of interest.

There is an important limit to this line of argument. Years of formal domain-relevant education are a good indicator of expertise. By contrast, small quantities of education may mean very little. In laboratory and field experiments, small doses of education often do not influence choice, particularly when the education is separated in time from the choice. For example, a two-page survey that taught people to take advantage of the employer match did not lead non-participants to enroll in their 401(k) plan (Choi, Laibson, and Madrian, 2005b), even though failing to reap the full employer match represented a pure arbitrage loss for survey recipients. ${ }^{15}$ Likewise, workplace educational seminars (Choi, Laibson, Madrian, and Metrick, 2006), simplified mutual fund fee disclosure forms (Choi, Laibson, and Madrian, 2006b, Beshears et al., 2008), and financial catastrophes due to underdiversification that befall other investors (Choi, Laibson, and Madrian, 2005a) have been shown to have very little impact on investment choices. This body of research implies that decision-making skills are difficult and costly to acquire or transmit.

\section{Conclusion}

Once economists acknowledge a gap between revealed preferences and normative preferences, it is natural to extend our models so we can model this gap. We have reviewed five factors that tend to increase the gap between revealed and normative preferences: passive choice, complexity, limited personal experience, third-party marketing, and intertemporal choice.

We have also discussed six ways of measuring normative preferences when they deviate from revealed preferences. Structural estimation specifies a positive model with a precise set of economic and psychological motives (perhaps including non-Bayesian thinking and other decision-making errors). This model is then estimated using data, and the resulting positive preferences are mapped into normative preferences using normative axioms.

\footnotetext{
15 The arbitrage opportunity exists for employees who are over age 591/2. They face no penalty for withdrawing funds from their 401(k) plan.
} 
Active decisions eliminate some biases generated by default regimes. Under an active decision regime, individuals are required to explicitly state their preference without being influenced by (or being able to rely on) a default option. In some circumstances, this preference elicitation will be more reliable and more socially efficient than allowing consumers to express their preferences by opting into or out of a pre-chosen default.

In most stationary economic environments, initial choices are likely to be further from normative optimality than choices made after many periods of experience. One should therefore give more weight to asymptotic choices when attempting to infer normative preferences.

When homogeneous individuals make noisy, error-prone decisions, their individual decisions do not reflect normative preferences, but their aggregate behavior can. Hence, normative preferences can sometimes be inferred from the central tendencies of aggregated preferences.

Self-reported preferences reveal something about an agent's goals and values. Normative economics should allow self-reports to have some standing. This is particularly true when self-reports can be used to distinguish confident consumer decisions from decisions that were made in a state of confusion.

Informed opinions come in two forms. External observers may offer expert advice, and decision-makers may themselves gain more expertise when they receive training or education. When trained/educated decision-makers make a choice, we call this an informed preference. Economists measuring normative preferences should give disproportionate weight to the actors who are most likely to know what they are doing.

This literature review leads naturally to the question of policymaking. Authors like Hayek (1944) and Friedman (1962) have convincingly argued that governments are not likely to successfully divine people's preferences and make optimal choices on their behalf. We agree. If we had to choose between government paternalism or consumer autonomy, we would take the latter without hesitation. Like most economists, we worry about the overconfidence, arrogance, and corruption of powerful political decision-makers.

In practice, however, we do not need to choose between the extremes of paternalism and autonomy. For example, consider the role of the medical doctor (or the car mechanic). Doctors are experts who advise their patients on decisions (and even make some decisions for their patients). On the other hand, the doctor's authority is only delegated authority. The patient or the patient's family is free to ignore the doctor's advice. The doctor plays an advisory role to an autonomous consumer.

Like doctors, the government (and other influential social institutions, like employers) are in a good position to advise autonomous agents without dictating to those agents. We believe that such advisory roles are appropriate, though they need to be monitored to reduce the likelihood of abuse. Governments could play a constructive advisory role if (1) their advice is only given in circumstances when the many different measures of normative preferences discussed above tend to coincide, and (2) their advice is offered without any obligation to 
obey (e.g. an opt-out default). ${ }^{16}$ By contrast, in cases with ambiguous or contradictory measures of normative preference, we side with Hayek and Friedman — government should withdraw.

\section{Acknowledgments}

The authors are grateful to participants at the "Happiness and Public Economics Conference" for their feedback, particularly Alan Manning.

\section{References}

1. Abadie A, Gay S. The Impact of Presumed Consent Legislation on Cadaveric Organ Donation: A Cross Country Study. Journal of Health Economics. 2006; 25:599-620. [PubMed: 16490267]

2. Afriat SN. The Construction of Utility Functions from Expenditure Data. International Economic Review. 1967; 8:67-77.

3. Agarwal, S.; Driscoll, JC.; Gabaix, X.; Laibson, D. Learning in the credit card market. 2007. Harvard University Working Paper

4. Ainslie, GW. Picoeconomics: The Strategic Interaction of Successive Motivational States Within the Person. Cambridge University Press; Cambridge: 1992.

5. Akerlof GA. Procrastination and Obedience. American Economic Review Papers and Proceedings. 1991; 81:1-19.

6. Anand S, Sen A. Human Development and Economic Sustainability. World Development. 2000; 28:2029-2049.

7. Angeletos G-M, Laibson D, Repetto A, Tobacman J, Weinberg S. The Hyperbolic Consumption Model: Calibration, Simulation, and Empirical Evaluation. Journal of Economic Perspectives. 2001; 15(3):47-68.

8. Ariely D, Loewenstein G, Prelec D. 'Coherent Arbitrariness': Stable Demand Curves Without Stable Preferences. Quarterly Journal of Economics. 2003; 118:73-105.

9. Aura, S. Does the Balance of Power Within a Family Matter? The Case of the Retirement Equity Act. 2001. IGIER Working Paper 202

10. Becker GS, Murphy KM. A Simple Theory of Advertising as a Good or Bad. Quarterly Journal of Economics. 1993

11. Bernheim, D.; Rangel, A. Beyond Revealed Preference: Choice Theoretic Foundations for Behavioral Welfare Economics. 2007. Stanford mimeo

12. Beshears, J.; Choi, JJ.; Laibson, D.; Madrian, BC. The Importance of Default Options for Retirement Savings Outcomes: Evidence from the United States. In: Kay, Stephen J.; Sinhas, Tapen, editors. Lessons from Pension Reform in the Americas. Oxford University Press; New York: 2006a. NBER Working Paper No. 12009. Forthcoming in

13. Beshears, J.; Choi, JJ.; Laibson, D.; Madrian, BC. Simplification and Saving. 2006b. NBER Working Paper No. 12659

14. Beshears, J.; Choi, JJ.; Laibson, D.; Madrian, BC. Simplified Disclosure. 2008. Harvard mimeo

15. Borger C, Smith S, Truffer C, Keehan S, Sisko A, Poisal J, Clemens MK. Health Spending Projections Through 2015: Changes on the Horizon. Health Affairs Web Exclusive. 2006; 25:W61-W73.

16. Camerer C, Issacaroff S, Loewenstein G, O’Donoghue T, Rabin M. Regulation for Conservatives: Behavioral Economics and the Case for 'Asymmetric Paternalism,'. University of Pennsylvania Law Review. Jan; 2003 Vol 151(No. 3):1211-1254.

17. Carroll, G.; Choi, JJ.; Laibson, D.; Madrian, BC.; Metrick, A. Optimal Defaults and Active Decisions. 2007. Harvard mimeo

\footnotetext{
${ }^{16}$ The Pension Protection Act of 2006 is an example of legislation that was based on many measures of normative savings preferences that are congruent and jointly deviate from the revealed savings preferences of many households.
} 
18. Centers for Disease Control and Prevention. Cigarette Smoking Among Adults — United States, 2000. Morbidity and Mortality Weekly Report. 2002; 51(29):642-645. [PubMed: 12186222]

19. Choi JJ, Laibson D, Madrian BC. Are Empowerment and Education Enough? Underdiversification in 401(k) Plans. Brookings Papers on Economic Activity. 2005a; 2005(2):151-198.

20. Choi, JJ.; Laibson, D.; Madrian, BC. \$100 Bills on the Sidewalk: Suboptimal Saving in 401(k) Plans. 2005b. NBER Working Paper No. 11554

21. Choi, JJ.; Laibson, D.; Madrian, BC. Reducing the Complexity Costs of 401(k) Participation Through Quick Enrollment. 2006a. NBER Working Paper 11979

22. Choi, JJ.; Laibson, D.; Madrian, BC. Why Does the Law of One Price Fail? An Experiment on Index Mutual Funds. 2006b. NBER Working Paper 12261

23. Choi, JJ.; Laibson, D.; Madrian, BC.; Metrick, A. Defined Contribution Pensions: Plan Rules, Participant Choices, and the Path of Least Resistance. In: Poterba, J., editor. Tax Policy and the Economy. Vol. 16. MIT Press; Cambridge: 2002. p. 67-113.

24. Choi JJ, Laibson D, Madrian BC, Metrick A. Optimal Defaults. American Economic Review Papers and Proceedings. 2003; 93:180-185.

25. Choi, JJ.; Laibson, D.; Madrian, BC.; Metrick, A. For Better or for Worse: Default Effects and 401(k) Savings Behavior. In: Wise, DA., editor. Perspectives on the Economics of Aging. University of Chicago Press; Chicago: 2004. p. 81-121.

26. Choi, JJ.; Laibson, D.; Madrian, BC.; Metrick, A. Saving for Retirement on the Path of Least Resistance. In: McCaffrey, E.; Slemrod, J., editors. Behavioral Public Finance: Toward a New Agenda. Russell Sage Foundation; New York: 2006. p. 304-351.

27. Cronqvist H, Thaler RH. Design Choices in Privatized Social-Security Systems: Learning from the Swedish Experience. American Economic Review Papers and Proceedings. 2004; 94:424-428.

28. DellaVigna S, Malmendier U. Paying Not to Go to the Gym. American Economic Review. 2006; 96:694-719.

29. Fishman, P.; Pope, DG. Punishment-Induced Deterrence: Evidence from the Video-Rental Market. 2007. Wharton mimeo

30. Friedman, M. Capitalism and Freedom. Phoenix Books: University of Chicago Press; 1962.

31. Gabaix, X.; Laibson, D.; Li, H. Extreme Value Theory and the Effects of Competition on Profits. 2005. Harvard University Working Paper

32. Gourinchas P-O, Parker JA. Consumption Over the Life Cycle. Econometrica. 2002; 70:47-89.

33. Harrod, RF. Towards a Dynamic Economics. Macmillan; London: 1948.

34. Hayek, F. The Road to Serfdom. 50th anniversary edition. University of Chicago Press; 1944.

35. Hewitt Associates. Survey Findings: Trends and Experiences in 401(k) Plans 2005. Hewitt Associates; Lincolnshire, IL: 2005.

36. Holden, KC.; Nicholson, S. Selection of a Joint-and-Survivor Pension. 1998. p. 1175-98.University of Wisconsin Institute for Research on Poverty Discussion Paper

37. Hortaçsu A, Syverson C. Product Differentiation, Search Costs, and Competition in the Mutual Fund Industry: A Case Study of S\&P 500 Index Funds. Quarterly Journal of Economics. 2004; 119:403-456.

38. Houthakker HS. Revealed Preference and the Utility Function. Economica. 1950; 17:159-174.

39. Investment Company Institute. 2006 Investment Company Fact Book.

40. Iyengar, SS.; Huberman, G.; Jiang, W. How Much Choice Is Too Much?: Contributions to 401(k) Retirement Plans. In: Mitchell, Olivia; Utkus, Stephen, editors. Pension Design and Structure: New Lessons from Behavioral Finance. Oxford University Press; Oxford, UK: 2004. p. 83-96.

41. Iyengar, SS.; Kamenica, E. Choice Overload and Simplicity Seeking. 2006. University of Chicago Graduate School of Business Working Paper

42. John Hancock Financial Services. Eighth Defined Contribution Plan Survey: Insight into Participant Investment Knowledge \& Behavior. John Hancock Financial Services; Boston: 2002.

43. Johnson EJ, Goldstein DG. Do Defaults Save Lives? Science. 2003; 302:1338-1339. [PubMed: 14631022]

44. Johnson EJ, Hershey J, Meszaros J, Kunreuther H. Framing, Probability Distortions, and Insurance Decisions. Journal of Risk and Uncertainty. 1993; 7:35-51. 
45. Kahneman D, Wakker PP, Sarin R. Back to Bentham? Explorations of Experienced Utility. Quarterly Journal of Economics. 1997; 112:375-405.

46. Laibson D. Golden Eggs and Hyperbolic Discounting. Quarterly Journal of Economics. 1997; 112:443-477.

47. Laibson D, Repetto A, Tobacman J. Self-Control and Saving for Retirement. Brookings Papers on Economic Activity. 1998; (No. 1):91-196.

48. Laibson, D.; Repetto, A.; Tobacman, J. Estimating Discount Functions with Consumption Choices over the Lifecycle. 2006. Harvard University Working Paper

49. Listokin, Y. What Do Corporate Default Rules and Menus Do? An Empirical Examination. 2006. Yale Law and Economics Research Paper

50. Little IMD. A Reformulation of the Theory of Consumer's Behaviour. Oxford Economic Papers. 1949; 1:90-99.

51. Loewenstein G, Prelec D. Anomalies in Intertemporal Choice: Evidence and an Interpretation. Quarterly Journal of Economics. 1992; 107:573-597.

52. Luce, RD. Individual Choice Behavior: A Theoretical Analysis. John Wiley and Sons; New York: 1959.

53. Madrian BC, Shea DF. The Power of Suggestion: Inertia in 401(k) Participation and Savings Behavior. Quarterly Journal of Economics. 2001; 116:1149-1187.

54. McClure S, Li J, Tomlin D, Cypert K, Montague L, Montague P. Neural Correlates of Behavioral Preference for Culturally Familiar Drinks. Neuron. 2004; Volume 44(Issue 2):379-387. [PubMed: 15473974]

55. McFadden, D. Econometric Models of Probabilistic Choice. In: Manski, CF.; McFadden, D., editors. Structural Analysis of Discrete Data with Econometric Applications. MIT Press; Cambridge: 1981. p. 198-272.

56. Nordhaus, W. The Stern Review on the Economics of Climate Change. 2006. Yale University Mimeo

57. O’Donoghue, T.; Rabin, M. Procrastination in Preparing for Retirement. In: Aaron, H., editor. Behavioral Dimensions of Retirement Economics. Brookings Institution Press; Washington D.C.: 1999a. p. 125-156.

58. O’Donoghue T, Rabin M. Doing It Now or Later. American Economic Review. 1999b; 89:103124.

59. Park CW, Jun SY, MacInnis DJ. Choosing What I Want Versus Rejecting What I Do Not Want: An Application of Decision Framing to Product Option Choice Decisions. Journal of Marketing Research. 2000; 37:187-202.

60. Phelps ES, Pollak RA. On Second-Best National Saving and Game-Equilibrium Growth. Review of Economic Studies. 1968; 35:185-199.

61. Pigou, AC. The Economics of Welfare. Macmillan; London: 1932.

62. Plott, CR. Rational Individual Behavior in Markets and Social Choice Processes: The Discovered Preference Hypothesis. In: Arrow, K.; Colombatto, E.; Perlaman, M.; Schmidt, C., editors. The Rational Foundations of Economic Behavior. St. Martin's Press; New York: 1996. p. 225-250.

63. Ramsey FP. A Mathematical Theory of Saving. Economic Journal. 1928; 38:543-559.

64. Samuelson PA. A Note on the Pure Theory of Consumer's Behaviour. Economica. 1938; 5:61-71.

65. Samuelson PA. Consumption Theory in Terms of Revealed Preference. Economica. 1948; 15:243253.

66. Shafir E, Simonson I, Tversky A. Reason-Based Choice. Cognition. 1993; 49:11-36. [PubMed: 8287671]

67. Solow RM. The Economics of Resources or the Resources of Economics. American Economic Review Papers and Proceedings. 1974; 64:1-14.

68. Stern, N. Stern Review on the Economics of Climate Change. HM Treasury; 2006.

69. Thaler, R.; Sunstein, C. Nudge: Improving Decisions About Health, Wealth, and Happiness. Yale University Press; 2008. 
70. U.S. Bureau of Labor Statistics. National Compensation Survey: Employee Benefits in Private Industry in the United States, 2003. 2005accessed January 15, 2007http://www.bls.gov/ncs/ebs/sp/ ebbl0021.pdf 